\title{
Nanoparticles as Potential Improvement for Conventional Fertilisation in the Cultivation of Raphanus sativus var. sativus
}

\author{
Lidia Mielcarz-Skalska, Beata Smolińska * (D) and Katarzyna Włodarczyk (D) \\ Institute of Natural Products and Cosmetics, Faculty of Biotechnology and Food Science, \\ Lodz University of Technology, Stefanowskiego 2/22, 90-537 Lodz, Poland; \\ lidia.mielcarz-skalska@dokt.p.lodz.pl (L.M.-S.); katarzyna.wlodarczyk@dokt.p.lodz.pl (K.W.) \\ * Correspondence: beata.smolinska@p.lodz.pl
}

Citation: Mielcarz-Skalska, L.; Smolińska, B.; Włodarczyk, K. Nanoparticles as Potential Improvement for Conventional Fertilisation in the Cultivation of Raphanus sativus var. sativus. Agriculture 2021, 11, 1067. https://doi.org/10.3390/ agriculture11111067

Academic Editors: Othmane Merah, Purushothaman

Chirakkuzhyil Abhilash, Magdi T. Abdelhamid, Hailin Zhang and Bachar Zebib

Received: 9 October 2021

Accepted: 26 October 2021

Published: 29 October 2021

Publisher's Note: MDPI stays neutral with regard to jurisdictional claims in published maps and institutional affiliations.

Copyright: (c) 2021 by the authors. Licensee MDPI, Basel, Switzerland. This article is an open access article distributed under the terms and conditions of the Creative Commons Attribution (CC BY) license (https:// creativecommons.org/licenses/by/ $4.0 /)$.
Abstract: The use of nanoparticles in fertilisation has confirmed positive effects on plant growth and yield. Simultaneously, there is still little research into the effects of nanoparticles on the antioxidant system of plants. Due to the positive effect of nano zinc oxide on plants and the special property of nano zero-valent iron, these particles were selected for the research. The nano zero-valent iron is crucial for plants as it is present in agglomerations on the surface of roots where it increases the absorptive surface of the rhizosphere and causes elongation of the roots. The study aims to determine the influence of selected nanoparticles as a potential improvement for conventional fertilisation by magnesium $(\mathrm{Mg})$, calcium $(\mathrm{Ca})$, phosphorus $(\mathrm{P})$ and nitrogen $(\mathrm{N})$. After the cultivation, the influence of nanoparticles on the accumulation of macronutrients in plant tissues, biometric parameters, and physiological response (chlorophyll and antioxidant system) of radish (Raphanus sativus) were assessed. The solution used in this study helped to increase the content of nitrates (V) in radish roots by $31.7-73.2 \%$ compared to conventional fertilisation. Nevertheless, nanoparticles supplementation resulted in a decrease in the concentrations of magnesium, iron ( $\mathrm{Fe})$ and zinc $(\mathrm{Zn})$ in plants. The high dose of used fertilisers increased the thickness and length of tubers by approximately $50.0 \%$, compared to the control samples. The "Macro 2 + nano" variant caused an increase of plant biomass up to $70.0 \%$. The analysis of the antioxidant system showed that the application of macronutrients with nanoparticles increased the concentration of polyphenols in plant tubers by $46.0-55.6 \%$. Interestingly, while implemented conditions caused a 1.5-fold increase in CAT activity in leaves, at the same time the decrease in CAT activity in plant roots was observed. Based on the obtained results of the enzymatic antioxidant system and biometric parameters of plants, it can be concluded that (in laboratory conditions) nZVI and nanoZnO are efficient components of fertilisers. However, the effects on other organisms must be investigated before implementing a method for widespread use.

Keywords: nano zero-valent iron; $\mathrm{ZnO}$ nanoparticles supplementation

\section{Introduction}

Soil fertilisation with nanoparticles shows promising results for agriculture, especially for crop production. Ramirez-Rodriguez et al. (2020) fertilised the durum wheat (Triticum durum) with conventional fertiliser and nanoU-NPK. The study demonstrated that the use of the aforementioned nanofertiliser allows plants to be supplemented with a lower nitrogen dose when compared to traditional fertilisers. According to the authors of the abovementioned article, this method shows not only slow nitrogen release but also better absorption and movement of nitrogen in plant tissues [1]. The research of Koureh in. (2019) [2] as well as Massri and Labban (2014) [3], consisted not only of fertilising plants with chemical NPK fertiliser, but also comparing it with other fertilisation methods (organic and mixed methods). The results of their work indicated that chemical fertilisers are effective, but mixed-methods obtained better results. Hasaneen et al. (2016) carried out NPK soil fertilisation combined with carbon nanotubes or nanoparticle chitosan where 
they grew French beans on this substrate. About 30 days after planting, a significant improvement in plant growth and biomass compared to the control was apparent. The study showed that nanofertilisers improved water and nutrient uptake, which resulted in plant growth stimulation. Moreover, nanofertilisers contributed to the harmonious release of nitrogen and phosphorus, which constitutes a potential solution to the existing problems of plant supplementation. Nitrogen $(\mathrm{N})$ and phosphorus $(\mathrm{P})$ are largely lost through chemical changes in the environment and natural leaching processes [4]. The use of nanoparticles improves the growth and yielding of plants. Furthermore, it allows one to reduce the need for conventional fertiliser, which means that application of their solution results in better use of nutrients by plants [5].

Conventional fertilisers, containing mainly a mix of the most necessary macronutrients (including phosphorus, nitrogen and calcium), for centuries, were necessary for the proper nutrition of plants. Unfortunately, the rapid growth of the human population, with the simultaneous reduction of agricultural land and increasing environmental pollution, indicates that the existing methods of growing plants are becoming insufficient. Additionally, fertilisation with traditional fertilisers is characterised by low absorption of nutrients for plants. These methods further caused many negative effects on the environment such as contamination of groundwater, degradation of soil quality and eutrophication of surface waters. The reasons for such effects are due to chemical fertilisers delivery of high concentrations of elements that are quickly released in disproportion to their uptake by plants [6].

Previous research on the influence of nanoparticles on plant growth and yielding (also in combination with conventional fertilisers) has mainly focused on plant growth. However, the information on the effect of these fertilisers on the antioxidant system of plants is scarce. Our study aims to fill this gap-to see how the combination of a fertiliser containing macronutrients and nanoparticles affects the antioxidant system. Its activation has positive effects-the plant's adaptability for unfavourable environmental conditions increase.

Based on the available research, we assume that the introduction of nanoparticles as fertilisation enhancers will increase the bioavailability of macronutrients. In addition, we will research the effect on the antioxidant system and the yield of selected plants.

The research was carried out on white radish-a plant belonging to the Brassiceae family, which among others includes common pepper (Lepidium sativum L.), cabbage (Brassica) and mustard (Sinapis). Radish accounts for about $2 \%$ of the world's vegetable production. It is grown on a larger scale mainly in Asian countries. In recent years, radish has furthermore been used as a model plant according to the OECD [7].

The work aimed to investigate the influence of nanoparticles as a potential improvement during soil fertilisation by macronutrients. The nZVI nanoFER 25 and nanoZnO with a particle size $<100 \mathrm{~nm}$ were used as nanoparticles. The research was conducted on white radish (Raphanus sativus var. Sativus). Two investigations were implemented in the study: the first (Macro) consisted of examining the plant's response to different concentrations of macronutrients $(\mathrm{Ca}, \mathrm{Mg}, \mathrm{P}$ and $\mathrm{N})$ - in low, optimal and high dosage. The second experiment (Nano) involved fertilising the soil with combined macronutrients at concentrations low, optimal and high dosage and using nanomicroelements at a constant concentration of $10 \mathrm{mg} \mathrm{kg}^{-1}$ per soil dry mass. These treatments aimed to determine whether the application of nanoparticles to soil with its simultaneous supplementation with macronutrients, affects the biometric and physiological parameters of radish. The obtained results revealed that nanoparticles used as fertilising substances have numerous advantages. In addition to stimulating the growth of radish, it has been proven that plants activate the antioxidant system, which leads to improved absorption of macronutrients.

In the future, research should be transferred from the laboratory to environmental conditions to investigate the influence of developed fertilisation methods on the environment. 


\section{Materials and Methods}

\subsection{Soil}

This research was conducted with soil with characteristics presented in Table 1 . The sandy loam was used with a density of $1.2 \pm 0.1 \mathrm{~g} / \mathrm{cm}^{3}$. The soil samples were analysed according to procedures described by Smolinska 2015 [8]. Additionally, the concentration of $\mathrm{Ca}, \mathrm{Mg}, \mathrm{Zn}, \mathrm{Fe}$, and Mn in soil was determined in accordance with UNE EN 13652:2002 [9].

Table 1. Soil characteristics.

\begin{tabular}{cc}
\hline Parameter & Content \\
\hline $\mathrm{C}_{\text {org }}$ & $6.74 \pm 0.35 \%$ \\
\hline $\mathrm{N}_{\text {total }}$ & $1.34 \pm 0.03 \%$ \\
\hline${\mathrm{N}-\mathrm{NO}_{3}{ }^{-}}^{\mathrm{N}-\mathrm{NH}_{4}}$ & $52.50 \pm 1.55 \mu \mathrm{g} \mathrm{g}^{-1}$ dry weight \\
\hline $\mathrm{Mg}$ & $97.40 \pm 4.24 \mu \mathrm{g} \mathrm{g}^{-1}$ dry weight \\
\hline $\mathrm{K}$ & $55.60 \pm 4.06 \mu \mathrm{g} \mathrm{g}^{-1}$ dry weight \\
\hline $\mathrm{Ca}$ & $3.80 \pm 0.47 \mu \mathrm{g} \mathrm{g}^{-1}$ dry weight \\
\hline $\mathrm{Fe}$ & $0.89 \pm 0.14 \mu \mathrm{g} \mathrm{g}^{-1}$ dry weight \\
\hline $\mathrm{Zn}$ & $59.60 \pm 7.91 \mu \mathrm{g} \mathrm{g}^{-1}$ dry weight \\
\hline $\mathrm{Mn}$ & $4.33 \pm 0.42 \mu \mathrm{g} \mathrm{g}^{-1}$ dry weight \\
\hline $\mathrm{P}_{\text {available }}$ & $37.50 \pm 6.72 \mu \mathrm{g} \mathrm{g}^{-1}$ dry weight \\
\hline $\mathrm{PO}_{4}{ }^{3-}$ & $0.38 \pm 0.04 \mu \mathrm{g} \mathrm{g}^{-1}$ dry weight \\
\hline $\mathrm{pH}$ & $1.34 \pm 0.66 \mathrm{mg} \mathrm{g}^{-1}$ dry weight \\
\hline
\end{tabular}

The soil was supplemented by macronutrients in concentrations given in Table 2 . The concentrations of macroelements were calculated based on the basis of "Fertilizer recommendations for field cultivation and permanent grassland" [10,11]. The dose of macronutrients was described as low, optimal, and high. In the second experiment, the soil was simultaneously supplemented by macronutrients in concentrations presented in Table 2 and microelements in the form of nanoparticles: nZVI ( 25 nanoFER from Nano Iron, Rajhrad, Czech Republic) and nanoZnO <100 nm (Sigma Aldrich) in concentrations of $10 \mathrm{mg} \mathrm{kg}^{-1}$ of soil dry weight.

Table 2. Concentrations of macronutrients were selected for the tests.

\begin{tabular}{lccccccc}
\hline \multirow{2}{*}{ Variant } & Concentration & $\mathbf{C a}$ & $\mathbf{M g}$ & $\mathbf{P}$ & $\mathbf{N}$ & $\mathbf{n Z V I}$ & nanoZnO \\
\cline { 3 - 8 } & low & 425 & 150 & 205 & 195 & - & - \\
\hline Macro 1 & optimal & 840 & 300 & 410 & 390 & - & - \\
\hline Macro 2 & high & 1260 & 450 & 615 & 585 & - & - \\
\hline Macro 3 & low & 425 & 150 & 205 & 195 & 10 & 10 \\
\hline $\begin{array}{l}\text { Macro 1 } \\
+ \text { nano }\end{array}$ & optimal & 840 & 300 & 410 & 390 & 10 & 10 \\
\hline $\begin{array}{l}\text { Macro 2 } \\
+ \text { nano }\end{array}$ & high & 1260 & 450 & 615 & 585 & 10 & 10 \\
\hline $\begin{array}{l}\text { Macro 3 } \\
+ \text { nano }\end{array}$ & & & & & & \\
\hline
\end{tabular}




\subsection{Green House Experiments}

The study on R. sativus seeds (W. Legutko, Poland) was conducted by sowing 5 seeds of chosen plant per 1 pot $(0.5 \mathrm{~kg}$ of the dry weight of soil). The samples were placed in fertilised soil except for the control samples, which were placed in the soil with no fertiliser. The plants were grown for 8 weeks in the greenhouse in a day/night system $(14 / 10 \mathrm{~h})$, with an average temperature of $22 / 19^{\circ} \mathrm{C}$ (day/night) and with constant air humidity of $50 \%$. During the whole period of cultivation, plants were irrigated with deionised water. The amount of water was suitable for keeping the humidity of soil approximately at the level of $35 \%$. After 8 weeks of cultivation radish plants were harvested and rinsed with deionised water to remove unnecessary soil particles. Finally, plants were weighed and further analysed [11].

\subsection{Analysis of Elements in Soil and Plant}

To calculate the concentration of crucial elements in the soil and plants such as $\mathrm{Mg}, \mathrm{Ca}$, Fe and Zn, the atomic absorption spectroscopy flame method (F-AAS) was employed. Prior to measurement, samples were mineralised with concentrated nitric $(\mathrm{V})$ acid in accordance with the procedure described by Turek, Wieczorek, and Wolf [12].

Nitrogen $(\mathrm{N})$ and phosphorus $(\mathrm{P})$ analysis in plant samples were preceded by the preparation of plant extracts. To obtain plant extract, $2.5 \mathrm{~mL}$ of distilled water was mixed with $0.4 \mathrm{~g}$ of plant material and $25 \mu \mathrm{L}$ of $25 \%$ sodium carbonate solution. Following samples were placed on a shaker at room temperature for $1 \mathrm{~h}$ followed by filtration. Next, samples were filled with water up to $4 \mathrm{~mL}$ [13]. Preparation of soil extracts for determination of $\mathrm{N}$ and $\mathrm{P}$ content was followed according to the procedure described by Sapak and Sapak, 1983. $10 \mathrm{~g}$ of soil was mixed with $200 \mathrm{~mL}$ of extraction solution (1\% potassium sulphate solution) and placed on a shaker for $1 \mathrm{~h}$. Finally, the samples were filtered and the first aliquot of the supernatant was discarded [14,15].

The content of nitrates $(\mathrm{V})$ in the samples was measured as follows. $10 \mathrm{~mL}$ of extracts were put into the test tubes. Next, $2-3$ drops of $0.5 \% \mathrm{NaOH}$ solution and $1 \mathrm{~mL}$ of sodium salicylate $(0.5 \%)$ solution were added. Subsequently, prepared samples were put in boiling water. After evaporation to a dry residue, $1 \mathrm{~cm}^{3}$ of concentrated sulfuric acid was added to each tube. After $10 \mathrm{~min}$, the samples were treated with distilled water and quantitatively transferred to a flask $(50 \mathrm{~mL})$. Additionally, $7 \mathrm{~mL}$ of an alkaline solution of sodium potassium tartrate were added to the samples. The last step of the procedure was filling the flask with distilled water up to $50 \mathrm{~mL}$. The measurement of absorbance proceeded at a wavelength of $\lambda=410 \mathrm{~nm}$ using a blank solution as a reference. The content of nitrates (V) in the sample was calculated based on the previously prepared standard curve [16].

The content of ammonium nitrogen was determined by adding $0.1 \mathrm{~mL}$ of sodiumpotassium tartrate solution and $0.1 \mathrm{~mL}$ of Nessler's reagent to $5 \mathrm{ml}$ of the sample. After $10 \mathrm{~min}$ of reaction, the absorbance of the solution was measured at a wavelength of $400 \mathrm{~nm}$. The ammoniacal nitrogen content in the sample was calculated based on the previously prepared standard curve $[17,18]$.

Determination of phosphate content was concluded as follows: $2.5 \mathrm{~mL}$ of the extract was transferred to test tubes. Then, $0.1 \mathrm{~mL}$ of ammonium molybdate solution and $0.025 \mathrm{~mL}$ of tin chloride solution were added. The samples were mixed. Afterwards, the absorbances of the samples were measured at $690 \mathrm{~nm}$ after 10 to $12 \mathrm{~min}$ from the moment of addition of chloride. Phosphate concentration was expressed in $\mathrm{mg} \mathrm{PO}_{4}{ }^{3-} \mathrm{g}^{-1}$, based on the standard curve [19].

\subsection{Plant Analysis}

\subsubsection{Plant Biomass and Biometric Parameters}

The harvested plants were collected. The shoots and roots were weighed separately for fresh biomass analysis. The results were compared with the control plant samples, grown without soil fertilisation. The biometric parameters of plants harvested from differ- 
ent cultivars (control, Macro or Nano variants) were determined in accordance with the procedure described by Smolińska and Szynkowska-Jóźwik (2021) [20].

\subsubsection{Chlorophyll and Plants Pigments Concentration}

Determination of plant pigments was performed in accordance with the procedure described by Israelstam and Hiscox (1979) [21]. Radish leaves were mixed with $2.5 \mathrm{~mL}$ of dimethylsulfoxide (DMSO) solution and left in the dark for $1 \mathrm{~h}$ at room temperature. After that samples were transferred to the water bath $\left(65^{\circ} \mathrm{C}\right)$ for $30 \mathrm{~min}$. Next, samples were centrifuged. The measurement of absorbance (UV/VIS8453 Spectroquant Nova 400 spectrophotometer (Merck KGaA, Darmstadt, Germany)), was conducted for 4 different wavelengths: $663 \mathrm{~nm}, 645 \mathrm{~nm}, 470 \mathrm{~nm}$ and $534 \mathrm{~nm}$. The content of individual plant dyes was calculated according to the formula proposed by Arnon (1949) [22] with the modification of Richardson et al. (2002) [23]. The results were given in $\mathrm{mg} \mathrm{g}^{-1}$ fresh weight of the plant.

\subsubsection{Non-Enzymatic Antioxidant System Analysis}

The content of polyphenol in R. sativus tissues was analysed according to the procedure developed by Cheng et al. (2009) [24]. The plant sample was triturated with $80 \%$ methanol. After $30 \mathrm{~min}$, the samples were centrifuged, and the supernatant was poured off. The next step of the procedure was to add distilled water and Folin's reagent and incubate the samples for $3 \mathrm{~min}$ at room temperature. Afterwards, the solution of $10 \%$ sodium carbonate was added to each extract. After $1 \mathrm{~h}$ incubation in the dark, the absorbance was measured at $725 \mathrm{~nm}$. The polyphenol content was calculated based on the previously prepared standard curve. As a reference for this measurement, the methanolic gallic acid solution was used. The total polyphenol content in samples was described as the amount of gallic acid equivalents per gram of fresh weight of the plant (mg GAE $\mathrm{g}^{-1}$ fresh weight) [25].

The content of flavonoids in Raphanus sativus was determined by using the procedure developed by Lamaison and Carnat (1990) [26]. Extracts were prepared by homogenising plant tissues with $80 \%$ methanol. Samples were mixed for $1 \mathrm{~h}$ and later centrifuged. The supernatant was decanted, and aluminium chloride was added. Samples were incubated for $30 \mathrm{~min}$ at room temperature. The last step of the procedure was the measurement of absorbance at $425 \mathrm{~nm}$. The content of flavonoids was calculated in accordance with the standard curve and results was expressed in $\mathrm{mg}$ of quercetin per $1 \mathrm{~g}$ of fresh weight of the plant (mg QE g ${ }^{-1}$ of fresh weight) [20].

\subsubsection{Enzymatic Antioxidant System Analysis}

To analyse the enzymatic antioxidant system, the determination of the activity of enzymes such as and catalase (CAT), pyrogallol peroxidase (POD) and superoxide dismutase (SOD) were vital.

The activity of superoxide dismutase (SOD) was determined using the procedure described by Roth et al. (1984) [27]. Plant tissues were treated with TRIS-EDTA buffer $(\mathrm{pH}$ 8.2) and incubated for $1 \mathrm{~h}$ at room temperature. Next, TRIS-EDTA and a $0.2 \mathrm{nM}$ pyrogallol solution were appended to the plant extracts. SOD activity was measured at $420 \mathrm{mn}, 10 \mathrm{~min}$ after the addition of pyrogallol. The activity of SOD was described as [ $\mathrm{U} \mathrm{g}^{-1}$ fresh weight] [25].

The activity of pyrogallol peroxidase (POD) was calculated in accordance with the methodology of Chance and Maehly (1955) [28]. The first step of the conducted procedure was homogenisation. Plant samples were homogenised with the use of acetate buffer ( $\mathrm{pH}$ 5.6), then mixed on a shaker for $30 \mathrm{~min}$ and lastly centrifuged. Acetate buffer $\mathrm{pH}$ 5.6, pyrogallol and $\mathrm{H}_{2} \mathrm{O}_{2}$ were added to obtained extracts. Parallelly, the samples without hydrogen peroxide were prepared. After $4 \mathrm{~min}$, the absorbances were measured at a wavelength of $470 \mathrm{~nm}$. The activity of the enzyme was calculated, based on the difference between the absorbance of samples with $\mathrm{H}_{2} \mathrm{O}_{2}$ and samples without $\mathrm{H}_{2} \mathrm{O}_{2}$ [mol g ${ }^{-1}$ fresh weight] [20]. 
The catalyse (CAT) activity was measured according to the method described by Jiang and Zhang (2002) [29]. Firstly, plant tissues were treated with phosphate buffer (pH 7.0) and then mixed for $30 \mathrm{~min}$. The plant extracts were mixed with the extraction buffer containing $\mathrm{H}_{2} \mathrm{O}_{2}$ and the phosphate buffer. To calculate the enzyme activity, the absorbance of the samples was measured until the value changed by 0.05 units at a wavelength of $240 \mathrm{~nm}$. Catalase activity was expressed in [ $\mathrm{U} \mathrm{g}^{-1}$ fresh weight] [20].

\subsection{Statistical Analysis}

The obtained results are presented in tables and figures. To evaluate the possibility of significant differences between the treatments, the ANOVA test was performed (using R-Studio). The LSD test (Fisher test) was simultaneously used. The obtained differences were considered statistically significant when the $p$-value $<0.05$.

\section{Results and Discussion}

\subsection{Concentration of Elements in the Soil and Plant Tissues}

One of the aims of the study was to explore the effect of chosen nanoparticles on the concentration of elements in the soil. The study demonstrated that their concentration was dependent on both the variant of the conducted process as well as the tested element. According to results presented in Table 3, it is portrayed that simultaneous application of two types of nanoparticles decreased the concentration of phosphates, nitrates (V), ammoniacal nitrogen $\left(\mathrm{N}-\mathrm{NH}_{4}\right)$, magnesium $(\mathrm{Mg})$ and zinc $(\mathrm{Zn})$ in soil when compared to control. Only calcium (Ca) and iron (Fe) amount in soil supplemented by nanoparticles increased about $13.0-26.1 \%$ and $18.6-37.8 \%$, respectively.

Nutrient presence in soil affects plant growth and the accumulation of elements in its tissues. The results of the study also revealed that the concentration of elements in plant roots was changed after nanoparticles application (Table 3). In all variants of the experiment, the conventional plant fertilisation led to the increase of the amount of tested nutrients when compared to control samples. The most spectacular increase was observed for magnesium - over threefold, in relation to control. The application of nanoparticles to soil influenced the concentration of tested elements in plant roots. The increase was observed for nitrate (V) - even 31.7-73.2\%, and no significant changes were noticed for calcium $(\mathrm{Ca})$ and ammoniacal nitrogen $\left(\mathrm{N}-\mathrm{NH}_{4}\right)$ concentration when compared to variants without nanoparticles. Unfortunately, the decrease of magnesium $(\mathrm{Mg})$, iron ( $\mathrm{Fe})$ and zinc (Zn) were observed in roots of radish supplemented by nanoparticles.

The influence of nanoparticles on the concentration of chosen elements in plants have already been extensively tested. Zhao et al. (2014) investigated the effect of ZnO nanoparticles on the content of elements in cucumber fruits. The concentration of $400 \mathrm{mg} \mathrm{kg}^{-1} \mathrm{ZnO}$ nanoparticles increased the magnesium $(\mathrm{Mg})$ content in its fruits. NanoZnO increased the concentration of zinc $(\mathrm{Zn})$ and manganese $(\mathrm{Mn})$, and the use of this type of nanoparticles decreased the concentration of molybdenum. There was no effect on the content of phosphorus (P) and sulfur (S) [30]. In the study presented by Zhao et al. (2014) the increase of $\mathrm{Ca}$ and $\mathrm{Mg}$ was observed after nanoparticles application. Dimkpa et al. (2017) explore the effect of $\mathrm{ZnO}$ nanoparticles on the growth of sorghum (Sorghum bicolor; var. 251). The NPK soil fertilisation with the addition of nanoparticles improved the accumulation of nitrogen $(\mathrm{N})$ and potassium $(\mathrm{K})$ and increased the zinc $(\mathrm{Zn})$ content in seeds. Additionally, increased uptake of magnesium $(\mathrm{Mg})$, manganese $(\mathrm{Mn})$, boron $(\mathrm{B})$ and copper $(\mathrm{Cu})$ was observed. The applied conditions had a negative effect on the iron (Fe) content in the sorghum tissues [31]. The results presented in Table 3 confirmed the findings of Dimpka et al. (2017). Nanoparticles used in the study increased the accumulation of nitrogen (N) in the form of nitrate $(\mathrm{V})$ and ammoniacal nitrogen $\left(\mathrm{N}-\mathrm{NH}_{4}\right)$ in radish roots. As in the study of Dimkpa et al. (2017) the iron concentration in plant roots decreased [31]. 


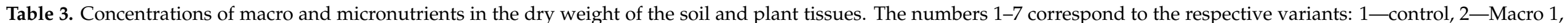

3-Macro 2, 4-Macro 3, 5-Macro $1+$ nano, 6-Macro $2+$ nano, 7-Macro $3+$ nano. Different letters indicate significant difference at $p<0.05$ by LSD test.

\begin{tabular}{|c|c|c|c|c|c|c|c|}
\hline & $\mathrm{PO}_{4}^{3-}\left[\mathrm{mg} \mathrm{g}^{-1}\right]$ & $\mathrm{NO}_{3}^{-}\left[\mu \mathrm{g} \mathrm{g}^{-1}\right]$ & $\mathrm{N}-\mathrm{NH}_{4}\left[\mu \mathrm{g} \mathrm{g}^{-1}\right]$ & $\mathrm{Mg}\left[\mu \mathrm{g} \mathrm{g}^{-1}\right]$ & $\mathrm{Ca}\left[\mu \mathrm{g} \mathrm{g}^{-1}\right]$ & $\mathrm{Fe}\left[\mu \mathrm{g} \mathrm{g}^{-1}\right]$ & $\mathrm{Zn}\left[\mu \mathrm{g} \mathrm{g}^{-1}\right]$ \\
\hline \multicolumn{8}{|c|}{ Roots } \\
\hline 1 & $0.727 \pm 0.07^{c}$ & $45.74 \pm 6.71 \mathrm{bc}$ & $83.99 \pm 7.19^{\mathrm{e}}$ & $88.89 \pm 5.75^{c}$ & $548.9 \pm 7.86^{\mathrm{cd}}$ & $63.33 \pm 4.69^{c}$ & $9.378 \pm 1.64^{a}$ \\
\hline 2 & $0.515 \pm 0.09^{\mathrm{cd}}$ & $41.75 \pm 7.71^{\mathrm{c}}$ & $91.17 \pm 5.24^{\mathrm{a}}$ & $264.7 \pm 6.17^{\mathrm{a}}$ & $882.4 \pm 7.64^{\mathrm{a}}$ & $78.82 \pm 5.45^{a}$ & $9.412 \pm 1.85^{a}$ \\
\hline 3 & $1.034 \pm 0.16^{\mathrm{a}}$ & $56.41 \pm 2.03^{b}$ & $88.44 \pm 6.86^{c}$ & $276.9 \pm 7.41^{a}$ & $853.9 \pm 11.2^{\mathrm{ab}}$ & $55.39 \pm 4.47^{\mathrm{d}}$ & $6.923 \pm 1.75^{c}$ \\
\hline 4 & $0.267 \pm 0.04^{d}$ & $89.80 \pm 3.79^{a}$ & $82.30 \pm 8.90^{\mathrm{e}}$ & $146.4 \pm 6.47^{b c}$ & $825.0 \pm 8.51^{\mathrm{ab}}$ & $46.43 \pm 5.28^{\mathrm{e}}$ & $6.214 \pm 1.93^{d}$ \\
\hline 5 & $0.034 \pm 0.01^{\mathrm{d}}$ & $54.92 \pm 4.80^{b}$ & $91.05 \pm 7.38^{a b}$ & $180.0 \pm 7.89^{b}$ & $765.0 \pm 33.3^{b}$ & $49.00 \pm 7.64^{\mathrm{de}}$ & $6.200 \pm 0.83^{d}$ \\
\hline 6 & $0.838 \pm 0.07^{b c}$ & $97.69 \pm 1.78^{a}$ & $90.33 \pm 4.42^{b}$ & $116.7 \pm 6.60^{c}$ & $853.3 \pm 6.53^{a b}$ & $56.00 \pm 5.99^{d}$ & $6.933 \pm 1.01^{\mathrm{c}}$ \\
\hline 7 & $0.098 \pm 0.01^{\mathrm{d}}$ & $47.78 \pm 3.00^{b c}$ & $78.69 \pm 5.97^{f}$ & $152.0 \pm 6.19^{b c}$ & $636.0 \pm 8.87^{c}$ & $53.20 \pm 7.30$ de & $9.280 \pm 1.99^{a}$ \\
\hline \multicolumn{8}{|c|}{ Soil } \\
\hline 1 & $0.679 \pm 0.08^{a}$ & $33.05 \pm 4.21^{\mathrm{b}}$ & $63.22 \pm 10.4^{a}$ & $32.33 \pm 6.68^{d}$ & $623.9 \pm 7.64^{b}$ & $40.47 \pm 6.71^{\mathrm{cd}}$ & $3.241 \pm 0.59^{b}$ \\
\hline 2 & $0.228 \pm 0.03^{c d}$ & $35.95 \pm 4.42^{b}$ & $51.49 \pm 8.98^{b}$ & $80.86 \pm 7.25^{a}$ & $865.4 \pm 8.02^{a}$ & $71.06 \pm 7.17^{\mathrm{a}}$ & $1.788 \pm 0.52^{\mathrm{cd}}$ \\
\hline 3 & $0.449 \pm 0.04^{b c}$ & $32.47 \pm 6.75^{b}$ & $42.06 \pm 9.99^{c}$ & $44.62 \pm 6.51^{b c}$ & $623.9 \pm 6.93^{b}$ & $38.41 \pm 5.92^{d}$ & $3.048 \pm 0.60^{b}$ \\
\hline 5 & $0.314 \pm 0.01^{b c}$ & $27.83 \pm 2.82^{c}$ & $60.36 \pm 9.66^{a}$ & $29.67 \pm 6.75^{d}$ & $728.3 \pm 7.80^{b}$ & $54.38 \pm 4.64^{\mathrm{bc}}$ & $2.048 \pm 0.26^{c}$ \\
\hline 6 & $0.296 \pm 0.04^{c}$ & $45.11 \pm 4.07^{\mathrm{a}}$ & $45.92 \pm 3.22^{c}$ & $39.62 \pm 6.44^{c}$ & $705.8 \pm 6.26^{b}$ & $48.01 \pm 7.16^{c}$ & $1.451 \pm 0.18^{\mathrm{cd}}$ \\
\hline 7 & $0.465 \pm 0.02^{b}$ & $33.28 \pm 6.88^{b}$ & $50.43 \pm 2.34^{b}$ & $40.88 \pm 7.78^{c}$ & $787.1 \pm 5.44^{\mathrm{ab}}$ & $55.77 \pm 7.23 b c$ & $1.711 \pm 0.33^{\mathrm{cd}}$ \\
\hline
\end{tabular}


During the conducted research the nano-iron was used to improve the macroelement accumulation by radish simultaneously with $\mathrm{ZnO}$ nanoparticles. The study of MonsefAfshar et al. (2012) explained that nano-iron fertilisation led to an increase Fe concentration in leaves of Vigna unguiculata [32]. In the presented study application of nZVI increased the Fe concentration in soil in reference to the control soil sample. However, the concentration of this element in radish roots decreased due to nZVI aggregation at the root surface. Moreover, the antagonistic effect of Fe and $\mathrm{Zn}$ can also occur which resulted in blocking the $\mathrm{Fe}$ and $\mathrm{Zn}$ access of both elements in the plant tissues [33,34]. All literature data suggest a large influence of the concentration and form of nanoparticles on the uptake of nutrients by plants. The results vary from plant to plant. For this reason, the results presented in this paper are consistent with some reports while contradicting others.

\subsection{Biometric Parameters}

The main objective of using fertilisers was to improve plant growth by providing nutrients that meet plant requirements. The effectiveness of fertilising substances can be assessed by measuring the plant biomass and its biometric parameters.

The results in Figure 1i indicate that soil supplementation with macronutrients did not provide a significant effect on the plant biomass, regardless of the used concentration. Moreover, the plant biometric parameters, such as the tuber thickness and length, as well as shoot length did not change for low and optimal concentrations of macroelements added to the soil (Macro 1 and Macro 2). Only the high dose of fertilisers increased the thickness and length of the tuber by around $50.0 \%$ when compared to control samples.

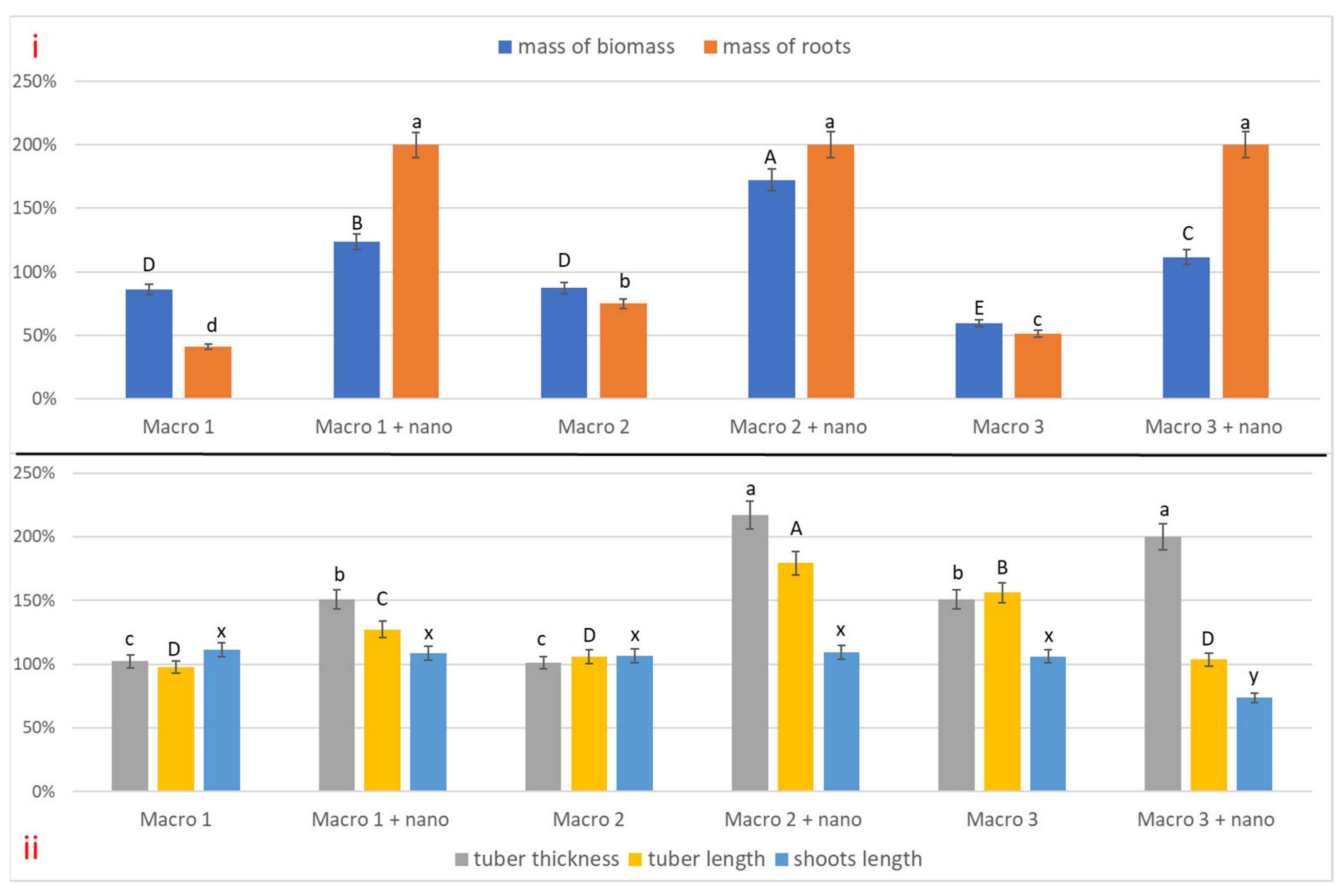

Figure 1. Plant biomass (i) and biometric parameters (ii) (\% compared to the control) after cultivation in soil supplemented macronutrients or macronutrients and nanoparticles. Vertical bars represent the mean values $(n=5) \pm$ standard deviations. Different letters indicate significant difference at $p<0.05$ by LSD test.

Significant growth of both plant biomass and biometric parameters was observed in all variants of an experiment conducted with the use of nanoparticles. All Nano-studies showed an over twofold improvement in the yield of white radish, in relation to control and Macro variants (Figure 1ii). Plant biomass increased by up to $70.0 \%$ in the "Macro 2 + nano" variant. The tuber thickness increased twofold. 
The results obtained in the study indicated that soil supplementation with macronutrients was not sufficient to improve the yield of radish, while the addition of nanoparticles significantly improved plant growth. The study stays in line with research provided by Kale et al. (2016), where eggplant (longitudinal nightshade-Solanum melongena L.) was cultivated, using various fertilisation methods: NPK and NPK + nanoZnO [5]. The use of nano $\mathrm{ZnO}$ resulted in a $9.0 \%$ improvement in yield and around a $46.0 \%$ increase of plant biomass in relation to the variant with NPK fertiliser [5].

\subsection{Chlorophyll a ib}

In the present study, the effect of soil supplementation by macronutrients and simultaneously macronutrients with nanoparticles on chlorophyll content in Raphanus sativus shoots were tested. Based on the results presented in Figure 2, the amount of chlorophyll $a$ and $b$ doubled in reference to the control plant sample, regardless of the variant of the experiment. The results suggested that both types of fertilisation encouraged plant physiological processes. An increase of chlorophyll content improves the efficiency of photosynthesis, which can increase plant biomass and yielding.

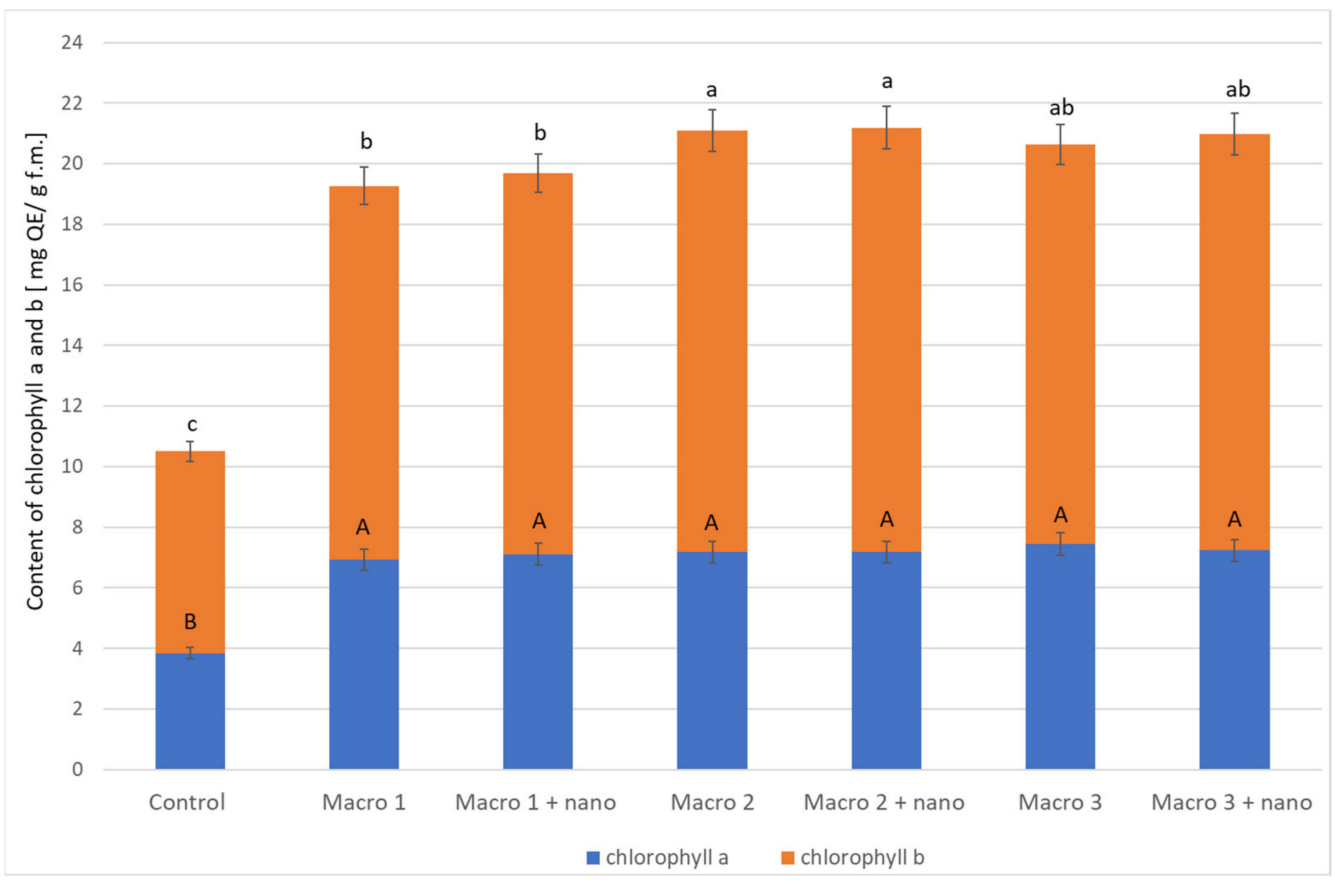

Figure 2. The content of chlorophyll $a$ and chlorophyll $b$ [mg g ${ }^{-1}$ fresh weight.] in the shoots of plants grown in soil supplemented macronutrients or macronutrients and nanoparticles. Vertical bars represent the mean values $(n=5) \pm$ standard deviations. Different letters indicate significant difference at $p<0.05$ by LSD test.

The obtained results confirm the research conducted by Neshev and Manolov (2015), who observed an increase of chlorophyll $a$ and $b$ content during conventional fertilisation [36]. The influence of nanoparticles on chlorophyll $a$ and $b$ production was tested by Dimkpa et al. (2017) [31]. The authors did not observe any significant changes under nanoZnO treatment, which was explained by the transformation of nanoparticles in their ionic form in the soil solution [31]. A partial chlorophyll degradation in Lepidium sativum L. was observed in the study of Mielcarz-Skalska and Smolińska (2018) [25]. They indicated that $\mathrm{ZnO}$ nanoparticles sized $<50 \mathrm{~nm}$ increased the pheophytins amount in plant shoot. These compounds are formed during chlorophyll degradation [25].

The results obtained in the study indicated that simultaneous application of macronutrients and nanoparticles positively influence plant physiological processes. 


\subsection{Non-Enzymatic Antioxidant System}

\subsubsection{Polyphenols and Flavonoids}

Non-enzymatic antioxidant system is formed by small lipophilic and hydrophilic compounds, such as polyphenols, flavonoids, carotenoids as well as ascorbic acid and tocopherols. During the conducted study the amount of polyphenols and flavonoids was determined.

Based on the results presented in Figure 3, the concentration of polyphenols was dependent on both parts of the tested plant and variant of the experiment (Macro or Nano study). In general, the amount of polyphenols was higher in plant shoots when compared to roots, with an exception of the Macro 3 variant. Moreover, it can be asserted that the concentration of polyphenols in radish cultivated in soil fertilised by macroelements decreased for the low and optimal doses of macronutrient added to the soil. Only high amounts of macronutrients led to an increase of the polyphenol content in plant roots. Concurrent application of macronutrients and nanoparticles increased polyphenols concentration by approximately $46.0-55.6 \%$ in plant tuber when compared to the control, regardless of the amount of added fertilisers.

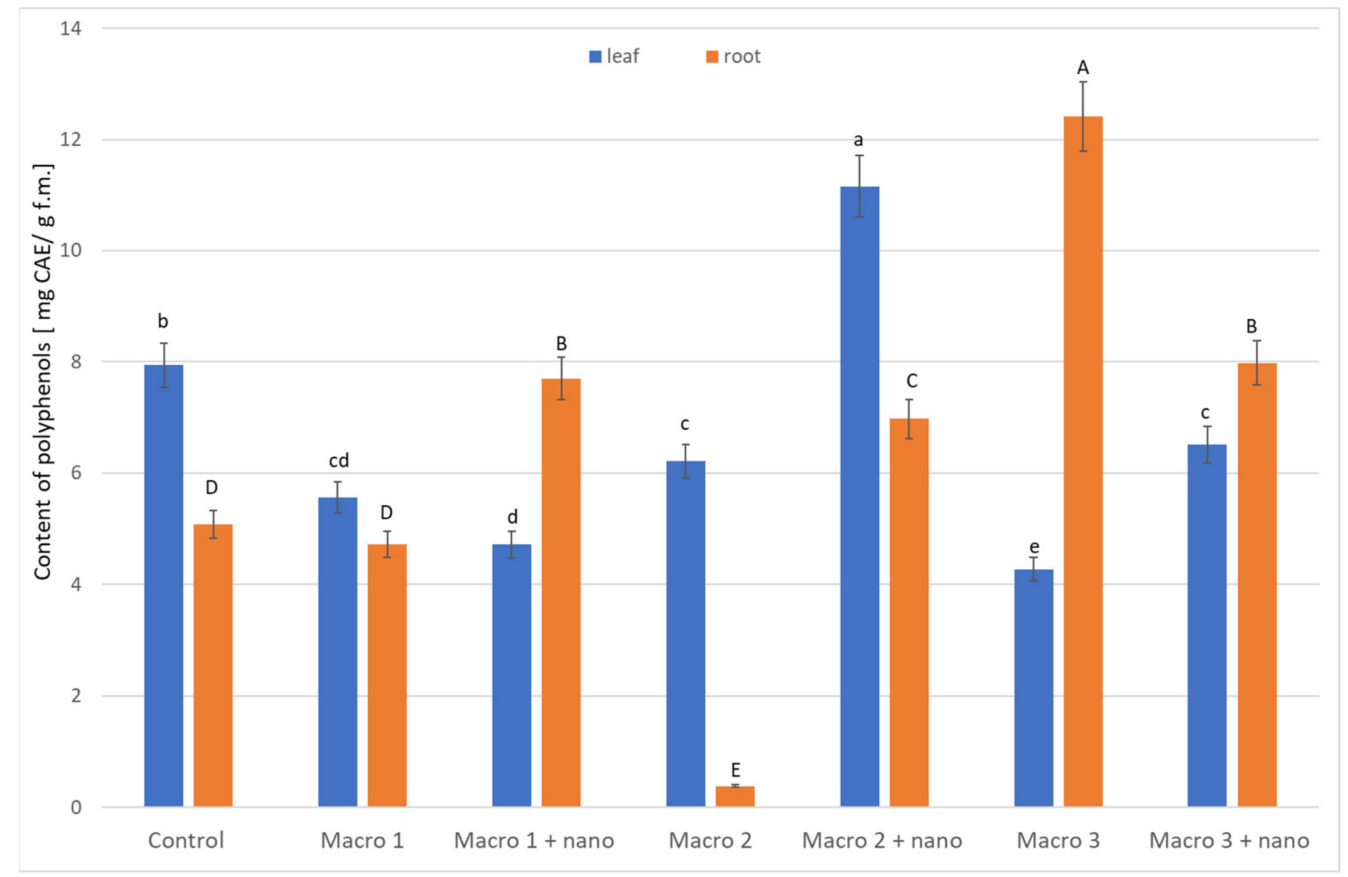

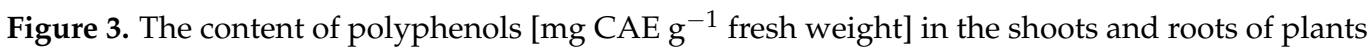
grown in soil supplemented macronutrients or macronutrients and nanoparticles. Vertical bars represent the mean values $(n=5) \pm$ standard deviations. Different letters indicate significant difference at $p<0.05$ by LSD test.

In comparison, it was observed that the addition of macronutrients stimulates the production of polyphenols only in the highest concentration. Moreover, the optimal concentration of macronutrients added to the soil as fertilisers caused inhibition of polyphenols production. This is an undesirable phenomenon due to the health benefits of polyphenols, especially in roots, which are particularly popular with consumers. This effect was eliminated by adding nanoparticles to the soil, where an increase in the production of polyphenols in the belowground part of the plant was observed at the lowest concentration of macronutrients (Figure 3).

Figure 4 presents the concentration of flavonoids in the radish shoot and root cultivated in Macro and Nano variants of the experiment. This study showed that under Macro study (Figure 4i) content of flavonoids in the aboveground tissues of $R$. sativus decreased by up to $70.0 \%$ in all macronutrient concentrations in reference to the control sample. However, the 
same conditions of plant cultivation led to an increase of flavonoid content in aboveground parts of radish, even twofold in reference to the control sample. Using nanoparticles as a potential improvement of fertilisation influenced the flavonoid concentration in plant tissues. In the variant when low and high concentration macronutrients + nanoparticles were employed, the amount of flavonoids decreased significantly in the plant shoots. Due to the health values of consumer plants, it was expected that flavonoids concentration would be kept at the same level or would increase in the root of $R$. sativus after Nano treatment. As shown in Figure 4, the application of nanoparticles led to an increase of flavonoids concentration in plant roots, even threefold in reference to control.

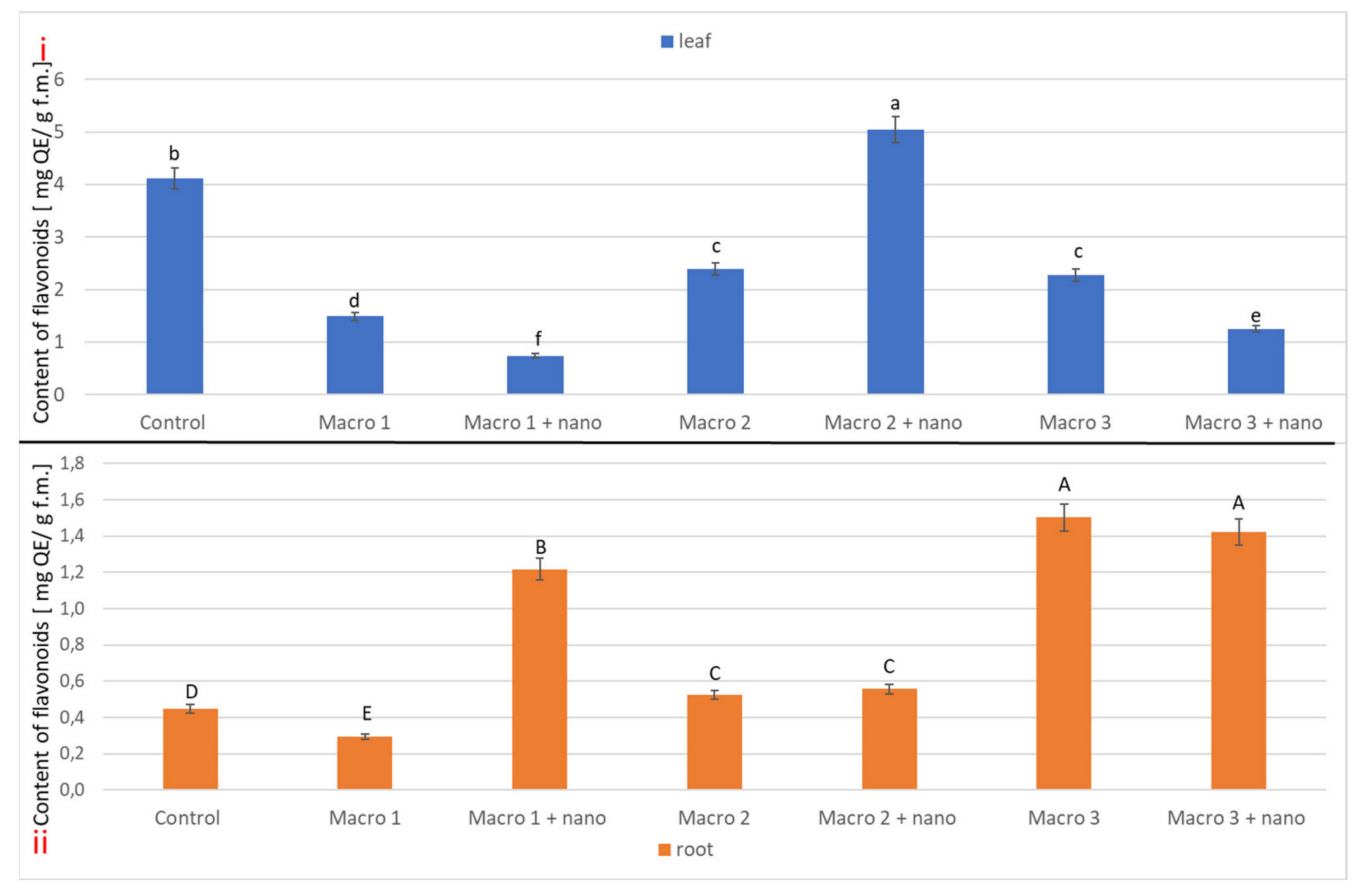

Figure 4. The content of flavonoids $\left[\mathrm{mg} \mathrm{QE} \mathrm{g}^{-1}\right.$ fresh weight] in the shoots (i) and roots (ii) of plants grown in soil supplemented macronutrients or macronutrients and nanoparticles. Vertical bars represent the mean values $(n=5) \pm$ standard deviations. Different letters indicate significant difference at $p<0.05$ by LSD test.

The results presented in the study constitute the confirmation of results obtained by Koureh et al. (2019), who indicated that plant fertilisation by NPK did not affect the flavonoids concentration in plant tissue but decreased the amount of polyphenols [2]. However, as demonstrated in the study of Mielcarz-Skalska and Smolińska (2018), ZnO nanoparticles sized $<100 \mathrm{~nm}$ positively influenced the amount of phenolic compounds in garden cress [25].

\subsubsection{Plants Pigments}

The non-enzymatic antioxidant system of plants is likewise formed by anthocyanin and carotenoids. During the study, the amount of these plant pigments were tested under different cultivar conditions. The results of anthocyanin concentration in $R$. sativus are demonstrated in Figure 5. Centred on the presented results it was established that the anthocyanin content in radish shoots decreased, regardless of cultivation conditions. Application of macroelements to soil led to a decrease of anthocyanin amount by up to $80.0 \%$ in all treatments in reference to control samples. At the same time, an increase in anthocyanin concentration in plant roots was observed. Comparison of results obtained from different cultivars (Macro and Nano study) demonstrated that the highest anthocyanin values were observed for medium macronutrient soil application, where the concentration of tested pigment increased even twelvefold when compared to control. This was the peak 
of obtained values. Promising results were observed in the variants where nanoparticles were used. Regardless of the macronutrient dose, nanoparticles led to an increase of anthocyanin amount about two to even eightfold when compared to control. Similar observations were obtained in the study of Hashemi et al. (2018), who tested anthocyanin concentration in soybean exposed to $\mathrm{ZnO}$ nanoparticles [37]. Syu et al. (2014) confirmed that $\mathrm{ZnO}$ nanoparticles increased the level of this plant pigment in Arabidopsis [35].

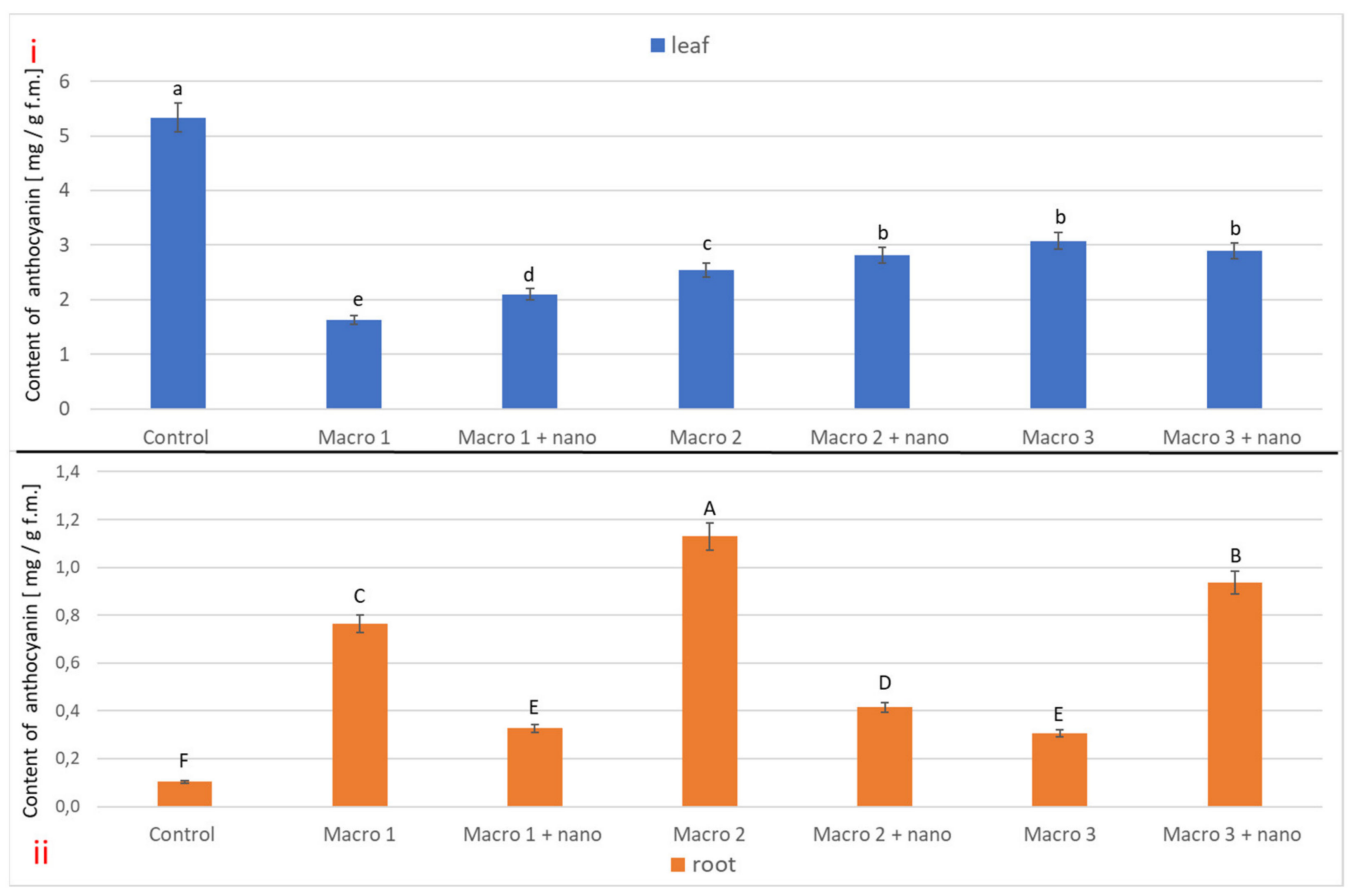

Figure 5. The content of anthocyanin $\left[\mathrm{mg} \mathrm{g}^{-1}\right.$ fresh weight] in the shoots (i) and roots (ii) of plants grown in soil supplemented macronutrients or macronutrients and nanoparticles. Vertical bars represent the mean values $(n=5) \pm$ standard deviations. Different letters indicate significant difference at $p<0.05$ by LSD test.

The additional plant pigments which concentration in radish was investigated within the study were carotenoids. Carotenoids are compounds that are involved in removing radical oxygen species from the cell, by quenching singlet oxygen and protecting chlorophylls, proteins and lipids from oxidative damage [37]. Based on the results presented in Figure 6, carotenoid levels in plant tissues were higher in plant leaves than in roots, regardless of the variant of plant cultivation. Comparison analysis of plant cultivation conditions revealed that using macronutrients as fertilisers increased the carotenoids content in plant leaves by about $29.5 \%, 45.9 \%$ and $43.2 \%$ for, respectively, low, medium and high doses of macronutrients added to the soil (Macro study) in reference to control samples. At the same time, the concentration of carotenoids in plant roots increased proportionally to the increasing dose of macronutrients applied to the soil.

Plant response to fertilisers and additional substances may vary depending on the growing condition and plant species. A study by Neshev and Manolov (2015) with two variants of fertilisation disclosed no effect of the applied conditions on the content of carotenoids [36]. In the study of Latef et al. (2017) lupine (Lupinus termis) was watered with three concentrations of nanoZnO with the plants growing on saline soil. The researchers observed an increase in the content of the non-enzymatic antioxidant system components, which included carotenoids in relation to saline soil conditions [38]. 


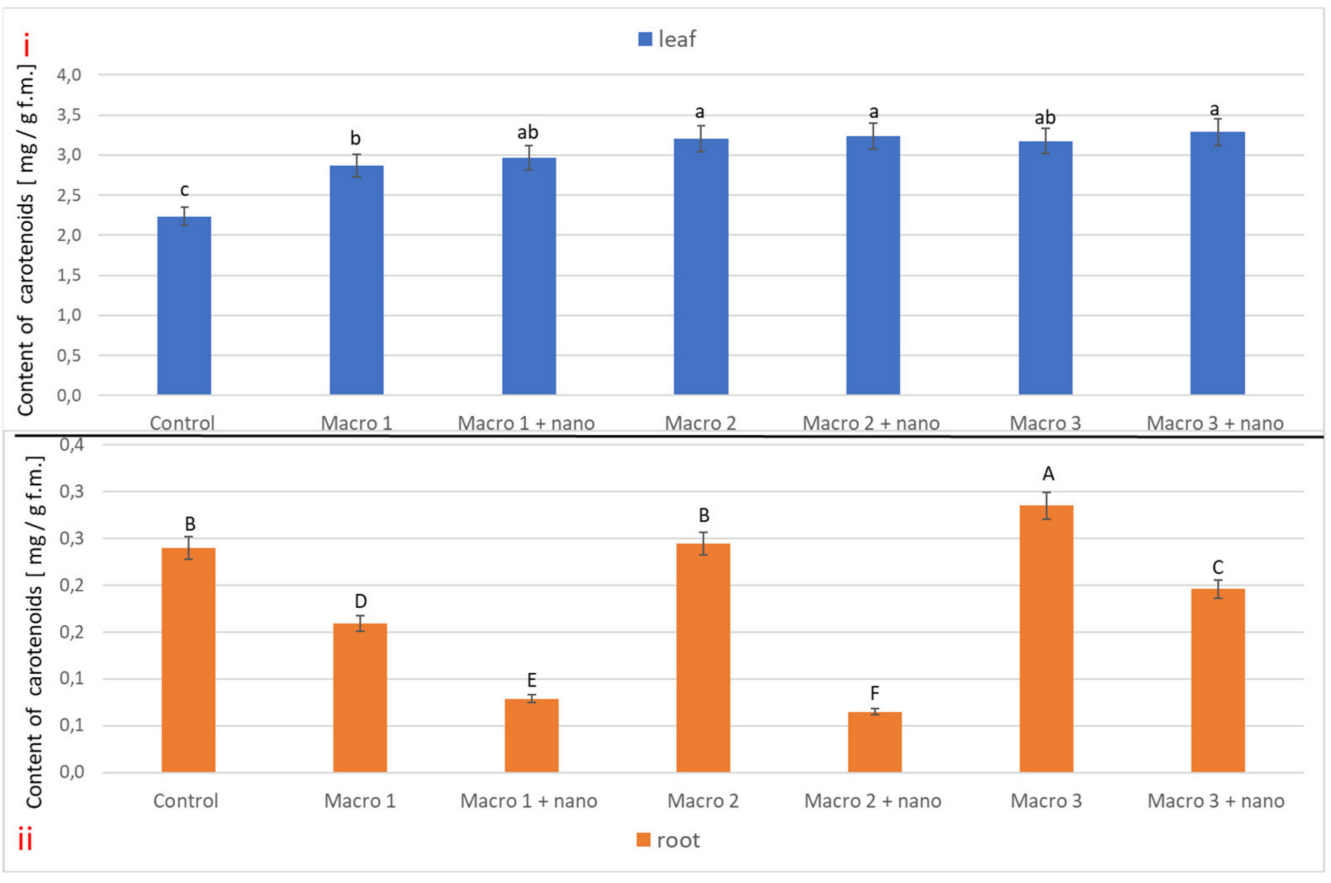

Figure 6. The content of carotenoids [ $\mathrm{mg} \mathrm{g}^{-1}$ fresh weight] in the shoots (i) and roots (ii) of plants grown in soil supplemented macronutrients or macronutrients and nanoparticles. Vertical bars represent the mean values $(n=5) \pm$ standard deviations. Different letters indicate significant difference at $p<0.05$ by LSD test.

\subsection{Enzymatic Antioxidant System}

One of the aims of the study was to determine the activity of the enzymatic antioxidant system of radish cultivated in soil supplemented by macronutrients and macronutrients with nanoparticles. The enzymatic antioxidant system is formed by enzymes which include superoxide dismutases (SOD), pyrogallol peroxidase (POD) and catalase (CAT) among others. These enzymes are vital in plant defence against ROS. Their main objective is to remove harmful ROS from plant cells or transform them into less toxic forms.

The results of SOD activity in radish roots and leaves are presented in Figure 7i. As demonstrated, SOD activity was lower in plant shoots than roots. However, no significant differences were observed for shoots and roots, regardless of plants cultivation conditions. SOD are enzymes that function consist of catalysation of dismutation of superoxide radicals to oxygen and hydrogen peroxide [39]. Hydrogen peroxide is a substrate for CAT that provides its dismutation to water and oxygen. The lack of significant differences in the activity of SOD suggests that the plant's function was not disturbed under-tested growth conditions. A further enzyme activity that was determined during the study was CAT activity. The results of these investigations are presented in Figure 7iii. A decrease in the activity of CAT in the plant roots was observed for treatment Macro 1. The same growth conditions led to a 1.5-fold increase of CAT activity in plant leaves. Soil supplementation with a fertiliser composed of selected macronutrients (Macro study) led to the increase of POD of about $34.0 \%$ in the variant Macro 2 in the aerial part when compared to control (Figure 7ii). No significant influence on this parameter was observed in the underground part of the plant. 


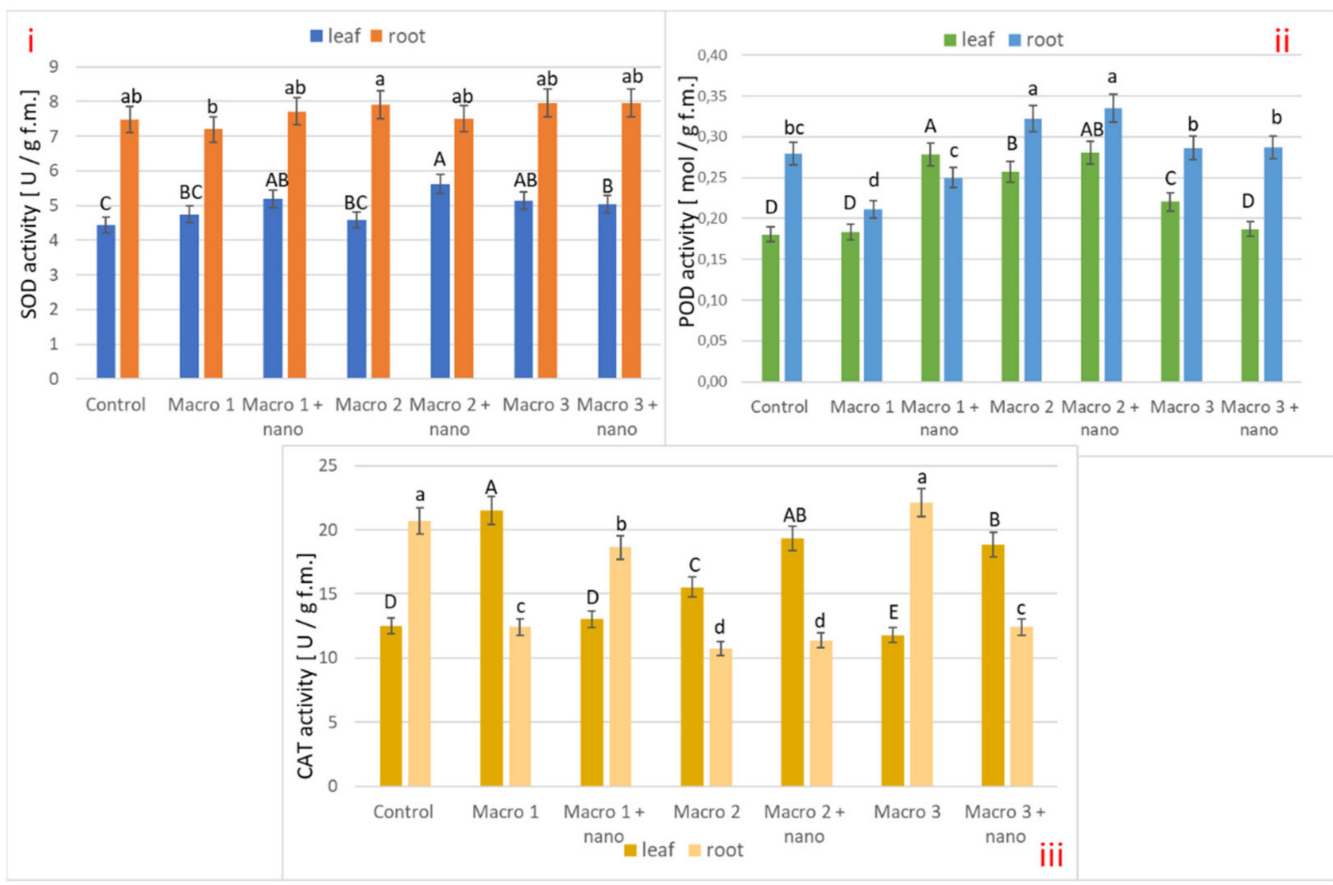

Figure 7. The content of superoxide dismutase [ $\mathrm{U} \mathrm{g}^{-1}$ fresh weight] (i), pyrogallol peroxidase [mol g ${ }^{-1}$ fresh weight] (ii) and catalase [ $\mathrm{U} \mathrm{g}^{-1}$ fresh weight] (iii) in the shoots and roots of plants grown in soil supplemented macronutrients or macronutrients and nanoparticles. Vertical bars represent the mean values $(n=5) \pm$ standard deviations. Different letters indicate significant difference at $p<0.05$ by LSD test.

Comparison of enzymes activity in plant tissues cultivated in the presence of nanoparticles indicated that SOD activity increased over $20.0 \%$ in the aerial part of radish in all variants of the experiment. Moreover, the applied conditions caused an about $50.0 \%$ increase activity of CAT in the radish leaves (Figure 7ii). The activity of CAT in the underground part of R. sativus (Figure 7iii) drops by half in variants "Macro $2+$ nano" and "Macro 3 + nano".

The obtained results are consistent with the results presented by Koureh et al. (2019) [2]. In a study by Koureh et al. (2019), the activity of DPPH increased in response to the application of NPK fertilisers [2]. The increase in the activity of the enzyme antioxidant system was similarly observed by Latef et al. (2017), during the cultivation of lupine watered with $\mathrm{ZnO}$ nanoparticles [38]. The study by Mielcarz-Skalska and Smolińska (2018), the cultivation of $L$. sativum on soil fertilised with nanoZnO (two sizes), showed an increase in SOD activity when growing with nanoparticles $<100 \mathrm{~nm}$. The smaller particles did not increase the activity of SOD and POD [25].

\section{Conclusions}

The results presented in the study showed that soil fertilisation by chosen macronutrients influenced plant growth and its biometric parameters. Soil incorporation by $\mathrm{N}, \mathrm{P}, \mathrm{Mg}$ and $\mathrm{Ca}$ increased slightly the plant below and aboveground biomass and $R$. sativus biometric parameters. This slight increase was reflected in the physiological and biochemical plant response to fertilisation. Although chlorophyll content increased, the concentration of non-enzymatic antioxidants, like polyphenols and flavonoids decreased in most variants of conducted process. Both plant pigments concentration and enzymes activity increased insignificantly. Only a high dose of used fertilisers positively affected radish growth. Using high concentrations of fertilisers is economically unjustified. Therefore, a possible solution to this problem was to improve the plant growth parameters and its physiological response by nanoparticles application to soil fertilised by macronutrients. 
Generally, nanoparticles used in the study increased the root and shoot biomass and enhanced the plant non-enzymatic and enzymatic antioxidant systems. However, it must be indicated that improvement of fertilisation by the use of nanoparticles was dependent on nanoparticles concentration. Even if the obtained results are promising, it must be remembered that the use of nanoparticles carries a certain risk, due to the lack of sufficient data on their impact on living organisms and their exact fate in the natural environment. In a conclusion, the simultaneous application of $\mathrm{nZVI}$ and $\mathrm{ZnO}$ nanoparticles improved the radish growth and its biochemical and physiological parameters. However, some further analysis must be conducted before method recommendation.

Author Contributions: Conceptualisation, B.S. and L.M.-S.; methodology, B.S. and L.M.-S.; formal analysis, L.M.-S. and K.W.; investigation, B.S., L.M.-S. and K.W.; data curation, B.S.; writing-original draft preparation, B.S., L.M.-S. and K.W.; writing-review and editing, B.S. and K.W.; supervision, B.S. All authors have read and agreed to the published version of the manuscript.

Funding: This research received no external funding.

Institutional Review Board Statement: Not applicable.

Informed Consent Statement: Informed consent was obtained from all subjects involved in the study.

Data Availability Statement: Not applicable.

Acknowledgments: This paper has been completed while the third author was the Doctoral Candidate in the Interdisciplinary Doctoral School at the Lodz University of Technology, Poland. Data sharing not applicable.

Conflicts of Interest: The authors declare no conflict of interest.

\section{References}

1. Ramírez-Rodríguez, G.B.; dal Sasso, G.; Carmona, F.J.; Miguel-Rojas, C.; Pérez-De-Luque, A.; Masciocchi, N.; Guagliardi, A.; Delgado-López, J.M. Engineering Biomimetic Calcium Phosphate Nanoparticles: A Green Synthesis of Slow-Release Multinutrient (NPK) Nanofertilizers. ACS Appl. Biol. Mater. 2020, 3, 1344-1353. [CrossRef]

2. Koureh, K.O.; Bakhshi, D.; Pourghayoumi, M.; Majidian, M. Comparison of yield, fruit quality, antioxidant activity, and some phenolic compounds of white seedless grape obtained from organic, conventional, and integrated fertilization. Int. J. Fruit Sci. 2019, 19, 1-12. [CrossRef]

3. Massri, M.; Labban, L. Comparison of Different Types of Fertilizers on Growth, Yield and Quality Properties of Watermelon. Agric. Sci. 2014, 5, 475-482.

4. Hasaneen, M.N.A.; Abdel-Aziz, H.M.M.; Omer, A.M. Effect of foliar application of engineered nanomaterials: Carbon nanotubes NPK and chitosan nanoparticles NPK fertilizer on the growth of French bean plant. Biochem. Biotechnol. Res. 2016, 4, 68-76.

5. Kale, A.; Gawade, S. Studies on Nanoparticle Induced Nutrient Use Eficiency of Fertilizer and Crop Productivity. Green Chem. Technol. Lett. 2016, 2, 88. [CrossRef]

6. Zulfiqar, F.; Navarro, M.; Ashraf, M.; Akram, N.A.; Munné-Bosch, S. Nanofertilizer use for sustainable agriculture: Advantages and limitations. Plant Sci. 2019, 289, 110270. [CrossRef]

7. Lukatkin, A.; Egorova, I.; Michailova, I.; Malec, P.; Strzałka, K. Effect of copper on pro- and antioxidative reactions in radish (Raphanus sativus L.) in vitro and in vivo. J. Trace Elem. Med. Biol. 2014, 28, 80-86. [CrossRef]

8. Smolinska, B. Green waste compost as an amendment during induced phytoextraction of mercury-contaminated soil. Environ. Sci. Pollut. Res. 2015, 22, 3528-3537. [CrossRef] [PubMed]

9. European Committee for Standardization. UNE EN 13652:2002. Soil improvers and growing media-Extraction of water soluble nutrients and elements. Sci. Hortic. 2002, 261, 13652.

10. Jadczyszyn, T.; Kowalczyk, J.; Lipiński, W. Zalecenia Nawozowe dla Roślin Uprawy Polowej i Trwatych Użytków Zielonych; Państwowy Instytut Badawczy: Warsaw, Poland, 2010.

11. Isherwood, K.F. Mineral Fertilizer Use and the Environment; IFA: Paris, Fance, 2000; Volume 50.

12. Turek, A.; Wieczorek, K.; Wolf, W.M. Digestion procedure and determination of heavy metals in sewage sludge-an analytical problem. Sustainability 2019, 11, 1753. [CrossRef]

13. Cherian, T.; Narayana, B. A new system for the spectrophotometric determination of trace amounts of nitrite in environmental samples. J. Braz. Chem. Soc. 2006, 17, 577-581. [CrossRef]

14. Sapak, B.; Sapak, A. Torf i Wyroby z Torfu Oznaczanie Azotu Amonowego BN-a3; Ośrodek Badawczo-Rozwojowy Produkcji Leśnej LAS: Skolimów, Poland, 1983; pp. 8-10.

15. Haney, R.L.; Franzluebbers, A.J.; Hons, F.M.; Zuberer, D.A. Soil C extracted with water or K2SO4: pH effect on determination of microbial biomass. Can. J. Soil Sci. 1999, 79, 529-533. [CrossRef] 
16. Strickland, J.D.; Parsons, T.R. A Practical Handbook of Seawater Analysis; Fisheries Research Board of Canada: Ottawa, ON, Canada, 1972; Volume 1.

17. Wu, H.Z.; Cao, A. Preparation and adding methods of Nessler's reagent having effects on determination of water quality ammonia nitrogen. Adv. Mater. Res. 2013, 726-731, 1362-1366. [CrossRef]

18. Jui, W. A Spectrophotometric Method for the Determination of Ammonia in Water; Department of Chemistry, The Chinese University of Hong Kong: Hong Kong, China, 1975.

19. Nivens, W.; Arora, P.H.; Emery, L.J.; Poff, J.G.; Schindler, S.C. 4500-P Phosphorus. Inorg. Nonmetals 1999, 4, $146-162$.

20. Mielcarz-Skalska, L.; Smolińska, B.; Szynkowska-Jóźwik, M. Comparison of the Impact of Different Types of nZVI on Lolium Westerwoldicum. Agronomy 2021, 11, 467. [CrossRef]

21. Israelstam, G.F.; Hiscox, J. A method for the extraction of chlorophyll from leaf tissue without maceration. Can. J. Bot. 1979, 57, 1332-1334.

22. Arnon, D.I. Copper enzymes in isolated chloroplasts. Polyphenoloxidase in Beta Vulgaris. Plant Physiol. 1949, 24, 1-15. [CrossRef]

23. Richardson, A.D.; Duigan, S.P.; Berlyn, G.P. An evaluation of noninvasive methods to estimate foliar chlorophyll content. New Phytol. 2002, 153, 185-194. [CrossRef]

24. Cheng, C.M.; Jalil, A.M.M.; Ismail, A. Phenolic and theobromine contents of commercial dark, milk and white chocolates on the Malaysian market. Molecules 2009, 14, 200-209. [CrossRef]

25. Mielcarz-Skalska, L.; Smolińska, B. Response of Lepidium sativum to soil contamination with zinc in molecular and nanoparticle form. World Sci. News 2018, 114, 55-67.

26. Lamaison, J.L.; Carnat, A. Levels of principal flavonoids in flowers and leaves of Crataegus-Monogyna Jacq and CrataegusLaevigata (Poiret) Dc (Rosaceae). Pharm. Acta Helv. 1990, 65, 315-320.

27. Roth, E.F.; Gilbert, H.S. The pyrogallol assay for superoxide dismutase: Absence of a glutathione artifact. Anal. Biochem. 1984, 137, 50-53. [CrossRef]

28. Chance, B.; Maehly, A.C. Assay of catalases and peroxidases. Methods Enzymol. 1955, 2, 764-775.

29. Jiang, M.; Zhang, J. Water stress-induced abscisic acid accumulation triggers the increased generation of reactive oxygen species and up-regulates the activities of antioxidant enzymes in maize leaves. J. Exp. Bot. 2002, 53, 2401-2410. [CrossRef]

30. Zhao, L.; Peralta-Videa, J.R.; Rico, C.M.; Hernandez-Viezcas, J.A.; Sun, Y.; Niu, G.; Servin, A.; Nunez, J.E.; Duarte-Gardea, M.; Gardea-Torresdey, J.L. $\mathrm{CeO}_{2}$ and $\mathrm{ZnO}$ nanoparticles change the nutritional qualities of cucumber (Cucumis sativus). J. Agric. Food Chem. 2014, 62, 2752-2759. [CrossRef]

31. Dimkpa, C.O.; White, J.C.; Elmer, W.H.; Gardea-Torresdey, J. Nanoparticle and ionic Zn promote nutrient loading of sorghum grain under low NPK fertilization. J. Agric. Food Chem. 2017, 65, 8552-8559. [CrossRef]

32. Monsef-Afshar, R.H.; Pirzad, A. Effect of Nano-iron foliar application on qualitative and quantitative characteristics of cowpea, under end season drought stress. Int. Res. J. Appl. Basic Sci. 2012, 3, 32.

33. Yirsaw, B.D.; Megharaj, M.; Chen, Z.; Naidu, R. Environmental application and ecological significance of nano-zero valent iron. J. Environ. Sci. 2016, 44, 88-98. [CrossRef]

34. Lefevre, E.; Bossa, N.; Wiesner, M.R.; Gunsch, C.K. A review of the environmental implications of in situ remediation by nanoscale zero valent iron (nZVI): Behavior, transport and impacts on microbial communities. Sci. Total Environ. 2015, 565, 889-901. [CrossRef]

35. Neshev, N.; Manolov, I. Influence of mineral fertilization on the leaf plastid pigment content and tuber quality of potatoes. J. Chem. Inf. Model. 2015, 53, 1689-1699.

36. Hashemi, S.; Asrar, Z.; Pourseyedi, S.; Nadernejad, N. Investigation of ZnO nanoparticles on proline, anthocyanin contents and photosynthetic pigments and lipid peroxidation in the soybean. IET Nanobiotechnol. 2019, 13, 66-70. [CrossRef]

37. Syu, Y.; Hung, J.H.; Chen, J.C.; Chuang, H.W. Impacts of size and shape of silver nanoparticles on Arabidopsis plant growth and gene expression. Plant Physiol. Biochem. 2014, 83, 57-64. [CrossRef] [PubMed]

38. Abdel Latef, A.A.H.; Abu Alhmad, M.F.; Abdelfattah, K.E. The Possible Roles of Priming with ZnO Nanoparticles in Mitigation of Salinity Stress in Lupine (Lupinus termis) Plants. J. Plant Growth Regul. 2017, 36, 60-70. [CrossRef]

39. Bowler, C.; van Camp, W.; van Montagu, M.; Inzé, D. Superoxide Dismutase in Plants. CRC Crit. Rev. Plant Sci. 1994, 13, 199-218. [CrossRef] 